\title{
The development of physic learning device by using problem based learning model approach characters value integration to increase learning out put
}

\author{
Eko Ambar Wibowo ${ }^{1}$, Festiyed ${ }^{2}$, Djusmaini Djamas ${ }^{3}$ \\ ${ }^{123}$ Universitas Negeri Padang, Padang - Indonesia, (ekoambarwibowo@gmail.com)
}

\begin{abstract}
The standard of content and the standard of process of curriculum 2013 require scientific learning and scientific learning character with more active studentsespecially in learning physics. Development model that was applied in this research was 4-D, which consists of defining, designing, developing and disseminating stages. Defining stagecovered curriculum, material and the student analysis. Designing stage covered the activity of formulating learning device in form of syllabus, Learning Implementation Plan, Module, Student Worksheet, the assessment of knowledge competition, manner, characters, and skills. On development stage the test of validity were done through validity sheet of learning device, practicality testing through observation sheet on the using lesson plan, questionnaire response of the teachers and the students, affectivity testing were obtained from the assessment of knowledge, attitude, characters, skill, and questionnaire of student's response. Disseminating stage is the activity to disseminate learning device valid, practice, and effective
\end{abstract}

Keywords: problem based learning model, lesson plan, characters value

\section{Introduction}

Education is a necessity that can not be separated from humans. If humans want to grow and improve knowledge, it must follow a continuous and programmed learning process. Mikarsa (2009: 12) states that education can affect human development in all aspects of personality and life.

Physics education emphasizes the provision of hands-on experience and practical activities to develop learning outcomes so that learners are able to explore and understand the natural surroundings scientifically. Physics Education is directed to find out "and" do "so it can help learners to gain a deeper understanding of the natural environment.

The government continues to develop national education system, especially in physics subject, to create qualified human resources. Various ways have been done by the Government include: improving the curriculum from the Curriculum Based Achievement learning (KBK), Education Unit Level Curriculum (KTSP) into the curriculum 2013, then efforts made from the school and teachers is 
to optimize learning tools and complement support facilities such as laboratories, libraries and other infrastructure. Then, researchers have also conducted various research on methods, models and strategies that are good to be applied in the learning process, especially physics as an effort to improve the quality of learning and the ability of the learners themselves.

Based on observations made on February 10, 2015 in SMA Negeri 6 Kerinci against learning tools used by teachers, still seen the low level of creativity of teachers in developing learning tools. This is evidenced based on a questionnaire distributed to 3 high school physics teachers N 6 Kerinci where, only $66.67 \%$ of teachers who have not developed their own devices in accordance with the needs of learners and the demands of the curriculum.

Teachers are still taking instructional tools from the National Education Standards Agency (BSNP) or taken from the MGMP agreement. Although there are already teachers who are trying to develop learning tools around $33.33 \%$, but still less focus on the ability and needs of learners. This is evidenced by 55 students who were given a questionnaire, $45.45 \%$ said that the learning activities are sometimes boring and saturated. This may be because the use of methods or learning models is less interesting and does not vary. This proves $30.91 \%$ of learners say sometimes teachers are just lectures in learning. Thus, causing the lack of opportunities of learners in conveying ideas and trying to solve problems regarding the material.

In addition, SWS is less interesting students. This is because teachers use SWS from the publisher, which causes less motivated learners and less active participation in learning. These problems ultimately affect the learning outcomes of learners, as shown in Table 1

Table 1. Daily Deuteronomy Result I class X students SMA N 6 Kerinci Lesson Year 2014/2015

\begin{tabular}{|c|c|c|c|c|c|c|c|c|}
\hline \multirow[t]{3}{*}{ No } & \multirow[t]{3}{*}{ Class } & \multirow{3}{*}{$\begin{array}{c}\text { The } \\
\text { number of } \\
\text { students }\end{array}$} & \multirow{2}{*}{\multicolumn{3}{|c|}{$\begin{array}{c}\begin{array}{c}\text { Average Daily } \\
\text { Deuteronomic Value }\end{array} \\
\text { Knowledge }\end{array}$}} & \multirow{2}{*}{\multicolumn{3}{|c|}{ \% Completeness }} \\
\hline & & & & & & & & \\
\hline & & & 1 & 2 & 3 & 1 & 2 & 3 \\
\hline 1 & XMIA1 & 35 & 61,30 & 63,37 & 56,04 & $46 \%$ & $48 \%$ & $36 \%$ \\
\hline 2 & XMIA2 & 35 & 55,34 & 57,59 & 51,49 & $43 \%$ & $45 \%$ & $34 \%$ \\
\hline 3 & XMIA3 & 35 & 53,78 & 54,33 & 50,28 & $40 \%$ & $42 \%$ & $31 \%$ \\
\hline
\end{tabular}

Based on Table 1 it is seen that daily optical device replay has a low value when compared with other daily test. In addition, teachers often only demand the end result undertaken by learners in the form of knowledge without accompanied by assessment of attitudes and skills of learners. This makes the learner prefer to imitate a friend's answer rather than think about where the results come from. This situation that still makes learning achievement of students have not reached Minimum completion criteria. Another cause of low learning achievement of learners, namely the lack of learning modules of interest in learning. An interesting learning module aims to increase the spirit of learners in learning.

Furthermore, although subject teachers have applied a model or approach to learning such as using Student Worksheets (SWS) in their activities, the SWS used by subject teachers is obtained from one publisher that is sometimes unsuitable for use. In addition, subject teachers also do not have a syllabus and a more specific Learning Implementation Plan (LIP) applies several models or approaches suitable for application in the classroom. Though the 2013 curriculum requires a scientific study consisting of observation, questioning, experimenting, processing data or information, presenting data or information, analyzing, reasoning, then concluding, and creating. Of course, scientific learning should be designed with good planning before it is put into syllabus, LIP, module, SWS, and appraisal so that it can be applied into the learning process using various learning models and approaches. In addition, the selection of models or approaches in learning, should also be seen 
from the characteristics of the material, learners, and support facilities in schools. Thus the assessment of the stance of attitudes including the values of the characters that students have, knowledge and skills can be done well too.

From the various problems above, it is possible will result in lack of learners activity in learning. Such activities such as learners are not fully involved in the process of observing which is an activity in optimizing all the five senses both in the field and through the medium of learning. Furthermore, physical activities such as conducting trials that do not use adequate SWS cause learners not actively involved in conducting activities. Thus it will affect the intellectual activities of learners that should be optimized such as measuring, processing, and presenting data.

One way that can be done to overcome this problem is by developing a device of learning physics in which using an integrated approach Saintifik character. Learning tools developed include syllabus, LIP, Module, SWS and assessment. The compilation of the tools is systematic, clear, specific and provides opportunities for learners to optimize their intellectual abilities through the problems faced daily. Syllabus and LIP are designed in accordance with the principles of its development. In addition, the module developed more guided learners to be able to observe the actual circumstances that occur in everyday environment so as to foster scientific attitudes and characters of learners.

Furthermore, SWS development will direct students to perform scientific work activities, process data or information, present data or information, analyze, reason, then conclude, and create so they gain the skills of science and character. Assessment developed will also direct learners to analyze and reason to measure the achievement of learning it has. Then the development of learning tools also pay attention to the model of learning and approach in accordance with the characteristics of the material being studied, learners, and supporting facilities in the school. Learning model that is considered appropriate is based on the model based problem learning integrated character values.

Model of learning problem based learning, is a learning model that emphasizes problem solving skills through systematic and scientific stages (following the steps of scientific method), in the process of learning problem based learning, learners have an active role to develop creativity berfiki through stages - a systematic stance so that learning is more centered on students (student centered). The steps of problem based learning, can be seen in

Table 2. Sintak Problem Based Learning Model

Phase

1. Provide an orientation about the problem to, educate

2. Organize learners to research

3. Assist in independent and group investigations

4. Develop and present the work and exhibit
Teacher Activity

Teachers discuss lesson objectives, describe important logistical needs, and motivate learners to engage in problem-solving activities.

Teachers help learners to define and organize learning tasks related to the problem.

Teachers encourage learners to get the right information, carry out experiments, and seek explanations and solutions.

Teachers assist learners in planning and preparing appropriate work, such as reports, videotapes, and models, and helping them to pass it on to others.

Furthermore, the values of characters proposed by Narwanti (2011: 16) which states that, "The nature of character education in the context of education in Indonesia is the value of education, the education of noble values sourced from the culture of Indonesia itself, in order to build personality young generation". Thus, character education is an education that instill and develop the noble values of the nation culture in the learners themselves to be internalized in each learner and apply it in life as 
a member of society and citizens who are religious, nationalist, productive and creative. This means that in addition to the understanding of learning materials that are taught in schools, learners are also required to have noble values of the nation's culture that is in learning. Thus, the values of character education developed in this study are Religious, Honest, Discipline, Hard Work, Want To Know, Cooperation, Confidence, Responsibility and Tolerance.

Learning outcomes are an expression of educational purpose, which is a statement about what is expected to be known, understood, and can be done by learners after completing a learning period. Learning achievement is the ability gained through the internalization of knowledge, attitudes, skills, competencies, and accumulated work experience.

According to Butcher (2006), achievement of learning (learning outcomes) is more focused on what is expected to be done by learners during or at the end of a learning process. While the "objectives" scope includes learning and teaching, and often used in the assessment process.

\section{Methodology}

The type of research to be conducted is the type of research and development (Research and Development) because in this study will be developed learning tools. Learning tools developed include LIP syllabus, SWS module, and assessment. Sugiyono (2010: 407) argued "Understanding research and development is a research method used to produce a specific product and test the effectiveness of the product.

This development research uses four-D (4-D) model development models, ie define, design, development and disseminate (Trianto, 2010: 189). This model has advantages such as: a) is more appropriate to be used as a basis for the development of learning devices rather than learning systems; b) the description seems more complete and systematic; c) in its development involves expert judgment, so that before the experiments conducted in the field of learning devices have been revised based on the assessment, advice and input of experts.

\section{Result And Discussion}

\section{Definition Stage (define)}

The defining stage is a process of analyzing the basic things required in the development of learning tools that include syllabus analysis, Learning Implementation Plan (LIP), module, SWS, and assessment. The purpose of the defining stage is to define the learning requirements by analyzing the learning objectives of the material developed into the learning tool by step analyzing each stage of the learning device component. The component analysis is as follows.

\section{Curriculum Analysis}

Curriculum analysis activities conducted on the curriculum 2013 using self evaluation instruments to obtain competencies that must be achieved by students through learning such as spiritual attitudes, social attitudes, knowledge and skills. Competence is reflected in the Core Competence (KI) and Basic Competence (KD). Then, from the curriculum analysis obtained learning approaches that should be used in the 2013 curriculum is an approach that leads to a scientific approach based on model problem based learning integrated character values. Evaluation tools for assessing consist of observation sheets of attitude observation, essay test for knowledge, and observation skill observation sheet.

\section{Material Analysis}

Stages of material analysis are guided by Handayani's explanation (2010: 54-55) that the learning materials consist of facts, concepts, principles, and procedures, so that the material analysis, the facts, concepts, principles and procedures of optical instrument material as shown in Table 2. 
Table 3. Facts, Concepts, Principles and Procedures of Optical Material Materials

\begin{tabular}{|c|c|}
\hline Material Type & Description \\
\hline \multirow[t]{3}{*}{ Fact } & Rabun away using minus glasses \\
\hline & Close rabbit uses positive glasses \\
\hline & Using a microscope can see small objects. \\
\hline \multirow[t]{2}{*}{ Concept } & Reflection \\
\hline & Refraction \\
\hline \multirow[t]{29}{*}{ Principle } & Lup: \\
\hline & Calculation In the maximum accomodated eye \\
\hline & $\mathrm{Si}=-\mathrm{PP}=-\mathrm{Sn}$ \\
\hline & $\frac{1}{s}=\frac{1}{c}+\frac{1}{c_{0}}$ \\
\hline & $\begin{array}{r}f \text { So }-S n \\
\text {. }\end{array}$ \\
\hline & $\begin{array}{l}\text { Magnification angle or angular magnification } \\
\qquad M=\frac{P P}{f}+1\end{array}$ \\
\hline & In the unaccommodated eye \\
\hline & $\mathrm{Si}=-\mathrm{PR}$ \\
\hline & So $=f$ \\
\hline & Magnification angle \\
\hline & $M=\frac{P P}{A}$ \\
\hline & $f$ \\
\hline & $M=$ angle magnification \\
\hline & $P P=$ point near eye in meter \\
\hline & $f=$ Distance of the focus lup in meters \\
\hline & Microscope: \\
\hline & Magnification of the microscope in the eye of the accommodation: \\
\hline & $M=M_{(O b)} \times M_{(O k)}$ \\
\hline & $M=\frac{S_{(O b)}^{\prime}}{S_{(O k)}} \times\left(\frac{P P}{f_{(O K)}}+1\right)$ \\
\hline & Description: $S(\mathrm{Ob})=$ Objective object lens distance in meters \\
\hline & $S^{\prime}(\mathrm{Ob})=$ Objective lens shadow distance in meters \\
\hline & $P P=$ point near observer in meters \\
\hline & $f(O k)=$ focal length of the ocular lens in meters \\
\hline & Observation using a microscope with the eye does not accommodate. \\
\hline & $S_{(O B)}^{\prime}(P P)$ \\
\hline & $M=\frac{(O b)}{S_{(O k)}} \times\left(\frac{11}{f_{(O k)}}\right)$ \\
\hline & $\mathrm{S}(\mathrm{Ob})=$ Objective object lens distance in meters \\
\hline & $\mathrm{S}^{\prime}(\mathrm{Ob})=$ Objective lens shadow distance in meters \\
\hline & $\mathrm{PP}=$ point near observer in meterf $(\mathrm{Ok})=$ focal length of ocular lens in meters \\
\hline Procedure & $\begin{array}{l}\text { - Students make observations, experiments solve problems, present, listen, and } \\
\text { respond to group work results according to procedures in SWS with steps based on } \\
\text { problem based learning model. }\end{array}$ \\
\hline
\end{tabular}

\section{Student Analysis}

Student analysis is done to find out the problems experienced by the students in the learning process, be it at home or at school and identify the characteristics of students. Mulyatiningsih (2012) states that teachers should recognize characteristics of students who will use teaching materials. The result of student's analysis using tool revealed problem which developed, result of research give 
result of student's interest toward physics class is low that is equal to $54,50 \%$, learner activity in study is low is $64,60 \%$ and interest of learners in studying physics still low ie $45.70 \%$. This certainly has an impact on learning achievement of learners. In addition, it will make learning more monotonous and less good interaction between fellow students or with teachers in the classroom and ultimately lead to the goal of learning is not achieved.

\section{Design Phase (design)}

After performing the analysis phase in the defining phase, the design of high school physics device based on the problem based learning model integrated character values. Character to be integrated is a character that is easily observed and adapted to the subject of physics that is the scientific character, plus other supporting characters. The characters are religious, honest, discipline, hard work, curiosity, cooperation, confidence, responsibility and tolerance. The designed devices include syllabus, LIP, modules, SWS and assessments that integrate into it character values.

\section{1) Syllabus}

Syllabus is a reference in the development of LIP that contains the identity of learning, KI, KD, subject matter, learning activities, assessment, allocation of time and learning resources. In the learning activities containing learning steps based on model problem based learning, and ended by presenting the work of SWS in front of the class. Furthermore, based on KI and KD that have been established by the government through content standards, the formulation of indicators of achievement of competencies is made.

\section{2) Learning Implementation Plan (LIP)}

The design of LIP is designed to be done systematically and contains the components of LIP writing as stated in Permendikbud. 65 on process standards, and follow the steps of LIP preparation. The learning activities are designed based on model problem based learning and integrated character values. The researcher designs four LIPs, each of which is used for a single meeting that is adjusted to the time allocation for each meeting. The material developed in the LIP for each meeting in sequence is a reflection of light on a flat mirror, a reflection of light on a concave and convex mirror, a refraction of light, and an optical instrument.

\section{3) Module}

The modules are designed tailored to the KI and KD curriculum set, and are developed as per the indicators and learning objectives to be achieved. The module then adjusted the steps of problem based learning. Modules designed in addition to complementing activities on the problem-based learning model also make the learning resource to explain reflectance and refraction events in optical devices.

\section{4) Student Work Sheet (SWS)}

Student Work Sheet (SWS) is designed in accordance with the sequence of steps in the problembased learning model. The learning steps in SWS begin by stimulating students' curiosity through visual activities through media or images in SWS, conducting experiments, analyzing data and concluding, and presenting the results of the activities in front of the class and being heard by all students. SWS design is made interesting so that students do not get bored and bored in doing SWS.

\section{5) Assessment}

Assessments designed include knowledge assessment, attitude assessment and skills assessment. The realm of knowledge relates to students' intellectual abilities. The attitude observed is the attitude of the students during the learning process. Skills observed are skills in carrying out experimental activities based on guidance in SWS. 
In the assessment of knowledge carried out a written assessment, the final test in the form of an essay in accordance with the indicators to be achieved and the level of difficulty of the problem. Problems created are the design of researchers who have been validated, and partly guided by the existing teaching materials.

\section{Development Stage (development)}

The development stage is the stage to produce high school physics device based on problem based learning model integrated values of characters that are valid, practical and effective, so it is worthy to be used in the learning process. The validator's validation of validation sheet consisted of 2 lecturers / lecturers of post-graduate physics UNP Padang, 1 lecturer / lecturer of UNP Graduate Education Technology, and 2 high school physics practitioners / teachers. Learning device validation results can be seen in Table 3

Table 4. Device Validation Results Learning

\begin{tabular}{lc}
\hline Device & Value \\
Syllabus & 0,93 \\
LIP & 0,92 \\
Module & 0,95 \\
SWS & 0,89 \\
Assessment & 0,92 \\
Average & $\mathbf{0 , 9 2}$ \\
\hline
\end{tabular}

Based on Table 4 and Category Device Validity, then with an average value of 0.92 can be concluded that the device is at intervals $\geq 61-100$ with valid categories

Practicality data obtained from the results of observation assessment of the implementation of LIP, teacher questionnaire response by two high school physics teachers and questionnaire responses of students of class X MIA 1 SMA Negeri 6 Kerinci against learning devices. The result of learning tool's practicality can be seen in Table 4 .

Table 5. Device Practical Results Learning

\section{Practical Data}

Implementation of LIP

Master's Response Questionnaire

Student Response Questionnaire

Average

Value (\%)
96,47
88,06
82,02
$\mathbf{8 8 , 8 5}$

88,85

Based on Table 5. note that learning tools are in the practical category. This is because the mean value of $88.85 \%$ is at intervals of $61-100$ when referring to the category of learning device practicity.

Data of learning device effectiveness is obtained based on student learning outcomes which include knowledge competence, attitude, character and skill as well as student response questionnaire. Results Effectiveness of learning tools can be seen in Table 5 .

Table 6. Learning Tool Effectiveness Results

\begin{tabular}{lc}
\hline Data Effectiveness & Value (\%) \\
Knowledge competence & 81,43 \\
Attitude Competence & 72,24 \\
Character & 72,24 \\
Skills Competencies & 92,99 \\
Average & $\mathbf{7 9 , 7 2}$ \\
\hline
\end{tabular}


Based on Table 6, it is known that the developed learning device has an average value of $79.72 \%$. Based on the effectiveness category of the device, then the value is at intervals 61-100 with effective category.

From the result of validity, the practicality and effectiveness of high school physics device based on the model of basesd learning problem integrated with the values of Character, it can be concluded that learning tools are suitable for use in the learning process.

\section{Conclusions}

Based on the development and experiments that have been done can be concluded that: Validation results from the validator shows that the learning tools physics SMA based model problem based learning integrated character values, valid. The mean values of the validation percentages obtained were 0.93 for the syllabus, 0.92 for the LIP, 0.95 for the module, 0.89 for SWS, and 0.92 for the assessment. In addition, based on the results of experiments, the physics of high school based on model based learning integrated values of characters, very practical with the average value of the percentage of practice obtained is 0.95 for the implementation of LIP, 0.97 for Master Question Questionnaire and 0,97 For questionnaire response of learners. The result of the experiment also stated that physics-based instructional device character education with problem based instruction model is very effective with the average value of practicality obtained from the teacher is 0.97 and from the student is 0.97 . The effectiveness of learning tools has also been proven by the increase of learning achievement and learning activities of learners.

\section{References}

Arends, Richard (2008). Learning to Teach. Penerjemah: Helly Prajitno \& Sri Mulyani. New York: McGraw Hill Company.

Butcher, C., Davies, C. and Highton, M. (2006) Designing Learning. From module outline to effective teaching. London and New York: Routledge

Handayani (2010) Bahan Ajar Perencanaan Pembelajaran. www.file.upi.edu (Diakses pada 20 April 2015)

Mikarsa,Hera Lestari,dkk.(2009). Pendidikan Anak di SD.Jakarta: Universitas Terbuka.

Narwanti, Sri. (2011). Pendidikan Karakter. Yogyakarta : Familia (Grup Relasi Inti Media)

Sugiyono (2010). Metode Penelitian Pendidikan Pendekatan Kuantitatif, Kualitatif, dan R\&D. Bandung: Alfabeta

Trianto. (2010). Mendesain Model Pembelajaran Inovatif-Progresif: Konsep, Landasan, dan Implementasinya pada Kurikulum Tingkat Satuan Pendidikan (KTSP). Jakarta: Kencana Prenada Media Group 